\title{
Indonesia in the Eyes of Australians through Media Coverage (A Qualitative Study about How Australians Portrays Indonesia)
}

\author{
Sri Seti Indriani ${ }^{1}$, Ditha Prasanti ${ }^{1}$ \\ ${ }^{1}$ Communication Faculty, Padjadjaran University, Indonesia \\ Correspondence: Sri Seti Indriani, ${ }^{1}$ Communication Faculty, Padjadjaran University, Indonesia.
}

Received: Apr. 7, 2020

Accepted: May 6, 2020

Online Published: May 12, 2020

doi:10.11114/smc.v8i1.4811

URL: https://doi.org/10.11114/smc.v8i1.4811

\begin{abstract}
Media reality, by far, tends to construct how people see things despite the objective reality. Indonesia, for this case, is a country that is known as its many conflicts and disasters through media coverage globally. Australia, as its neighbour, has also come to have some conclusions about Indonesia through the Australian Media, which then gives a sense of knowledge about Indonesia. The purpose of this research is to acknowledge how Australian Media portrays Indonesian and how the Australians perceive Indonesia because of it. This qualitative research conducted interviews with some Australians that are concerned about Indonesia.

The result of the study concludes that the media portrays Indonesia less as a tourists place, even though it was advertised repeatedly but more like an unorganized, chaotic place for pedestrians and commuters. Indonesia is seen as a country full of disasters and conflicts which signals that the country needs a hand from Australia. It is seen as a violent and dangerous place.

Despite the media coverage of Indonesia, and their agreement of Indonesia as a chaotic and dangerous place, Australians still consider Indonesia as a beautiful tourist place to go. Most believe that Indonesia is a young nation that is still developing, and as a young nation, it often has many issues, so it tends to be unorganized. The media has succeeded to portray Indonesia as it is.
\end{abstract}

Keywords: Indonesia, Australians, Media coverage, Australian media and media reality

\section{Introduction}

"Reality" has always been a concern since the earliest days of mass media. Researchers, social critics, politicians, and the general public have been questioning the extent to which media representations reflect or deviate from "reality" (M. Morgan, 2008). "Reality" can be confusing; some people nowadays consider that what media present as a "reality' is the real reality. People assumed information from the media being the truth even they do not experience it themselves. Living in two worlds, which is the real world and the media world create two different reality, though it also leads to multidimensions of reality. This multiple dimensions of reality construct the public to judge reality continuously. Media reality, by far, tends to construct how people see things despite the objective reality. Media with so many unavoidable constraints creates information which seemingly leads to bias and creates perspectives and stereotypes for the public. Nowadays, society facilitates information of the world through more significant media roles which the media plays. Today's media uses valuable communication achievements tools and techniques which manages to reach every member of society. This results on shared convictions and beliefs influenced by the media. Media creates stereotypes of various persons or social categories (Vavla \& Hasalla, 2015).

It is undeniable that there is a changing pattern on how people view because there are more devices in homes and extensive content choices. However, most countries still see television as the most reliable source of information, including Australians. The broadcast TV watched on in-home TV sets are still very common. There are 19.64 million Australians ( $82.6 \%$ of the population in people metered markets) watch broadcast TV in 2017. Australians were reported to have spent an average of two hours and 27 minutes watching live TV (Nielson, 2018). 37\% of Australians agree that they like to shut themselves off from the rest of the world when they're at home. Television networks and their advertisers continue to have the widest reach among Australians in the home (R. Morgan, 2019). Even though Television in Australia is still in their actual function to spread information, Australians also see the new media to gather more information and grasp more knowledge about the world. They turn to the new media to try to comprehend information. The new media has been seen 
to be a media to get more updated information, including information about Indonesia.

The digital television in Australia is categorized by nationwide, metropolitan and regional. Australian Broadcasting Corporation (ABC) and Special Broadcasting Service (SBS) are government-funded broadcast TV channels that are available nationwide. These channels also have online media coverage, so its availability can be reached worldwide. This research takes these two channels because of its availability on how they portray Indonesia.

Indonesia, for this case, is a country that is known as its many conflicts and disasters through media coverage globally. Media coverage sometimes can create intense effect on the society. Findings suggest that television viewing in the aftermath of a disaster may make a small contribution to subsequent posttraumatic stress symptomatology especially to children or that increased television viewing may be a sign of current distress and that it should be monitored (Pfefferbaum et al., 2001). Australia, as its neighbour has also come to have some conclusions about Indonesia through the Australian Media, which then gives a sense of knowledge about Indonesia. Figure 1 is one of many examples of media coverage on Australian Media about Indonesia from abcnews.go.com. The title of the information has a problematic issue about Indonesia which is related to the coronavirus. 'Angry inmates have set fire to an overcrowded prison on Indonesia's Sulawesi island during a riot over measures imposed to contain the coronavirus' (Wakary, 2020). The news coverage on this issue did not focus on the virus, but more to the prison riot in Indonesia.

\section{Coronavirus measures trigger prison riot in Indonesia}

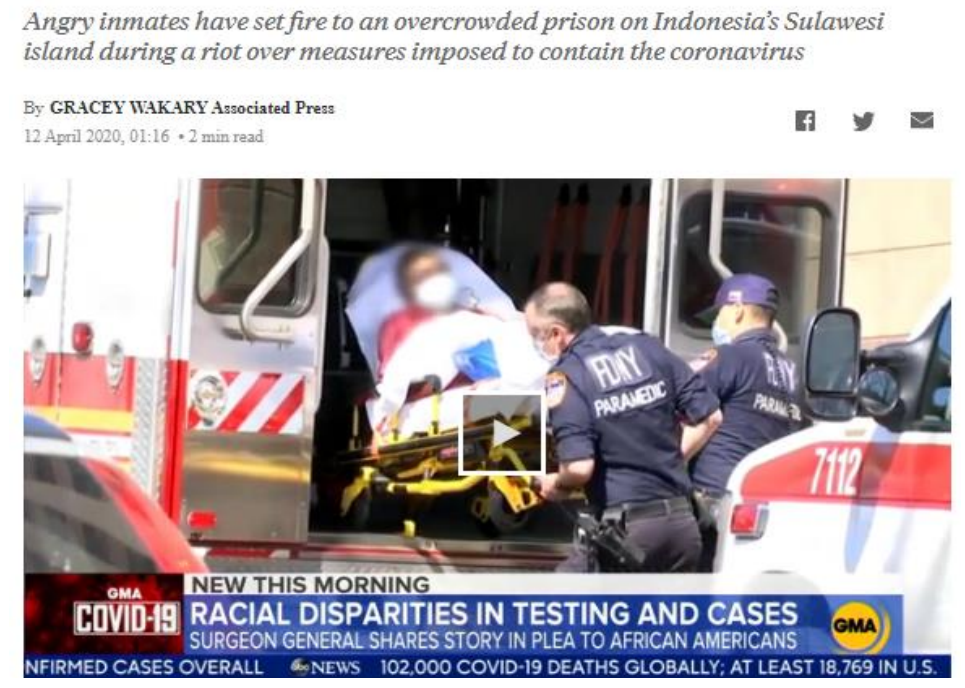

Figure 1. News Title about Indonesia in the Australian

Source: https://abcnews.go.com/

Another news found recently linked to the coronavirus but seemingly problematic for Australians to see was that some 70,000 animals across Indonesia are at risk of starvation as zoos struggle financially due to social distancing restrictions amid the coronavirus pandemic (Harvey, 2020). Often the public judge situation, condition, certain people or a country in the society with only superficial cues. The public does not have any actual contact with what they judge. The growth of the Internet has become an enormous tool to access media in addition to other traditional channels such as television, radio or newspapers. This access has made society utterly dependent and has made media an essential factor which creates perceptions and even affects the education of whole society categories. The media coverage about Indonesia, which the Australian Media portrays seemed to give assumptions about Indonesia for the Australian people. The purpose of this research is to acknowledge how Australian Media portrays Indonesian and how the Australians perceive Indonesia because of it.

\section{Literature Review}

\section{Media Reality}

The reality, as mentioned to be multidimensional, can also be divided into three; objective reality, subjective reality and the media reality. The society is what we call the objective reality, which are facts on what we see or experience genuinely happens. The subjective reality is when the public interprets the information subjectively. Then the media reality is a reality which is created by the media. The media reality is created because there is a tendency of unavoidable constraints. Some unavoidable constraints relate to deadlines and resource limitation. Deadlines of a reporter in gaining information 
might contribute to the lack of actual evidence on a situation. Reporters do not have that much time to construct a piece of full onboard information which leads on to misinterpretation for the public. Limited resource is also one of the obstacles on a reporter, gaining access to a piece of information is not that easy. Moreover, if so a reporter can gain access, it is another question on whether or not the resource is trustable and competent.

As mentioned before, the public received more considerable information through the media and not through experience, large portions of what the public knows or what they think they comprehend based not on the first-hand experience, but media representations of life, society, groups, and institutions (Hoffman \& Glynn, 2013). As what Hoffman and Glynn stated that perceptions of reality, rather than actual observations of reality, guide human beliefs, attitudes, and behaviours (Hardt, 2002). This perception of reality is an interpretation of media reality. Hardt relates to Luhman's opinion about the mass media system. The mass media system is managed through internal codes which enables the system to choose information from its environment that is convenient with its reflexive criteria (Vera, 2016).

There have been many kinds of research that are concern about how the media represent reality. Suryadi stated that the reality of media as a public space often could not play themselves as a neutral party. It always involved with efforts to reconstruct social reality. The mass media was always involved in presenting the reality, arranged in such a way that it did not reflect the actual reality. The reasons were about the variety of technical, economic, and ideological reasons (Suryadi, 2011). Another research pointed out that the media was very substantial in the process of externalization, subjectivism, and internalization in constructing social reality (Santoso, 2016). The role of mass media was also criticized on constructing of people outside the national mainstream or other nationalities. This study explained how the media promote or hinder a positive outlook on cultural diversity. It identified obstacles to fair representations in media production, content and reception. (Fürsich, 2010). An example on how Media portrayals another country here is a study on how American Media portrayals Vietnam, despite on the progress of diplomatic relations between both countries, the American Media portrays Vietnam remained unchanged which was a long-term and volatile relationship between these two countries (Vu \& Lee, 2012).

Society needs to criticize more on what the media presents about reality, especially on television. Television as what Shrum calls is an amusement park. The society should not go to television if they want to seek the truth. Though, in the past few years, there have been improvements in how televisions represent reality, especially with programs that are called "reality show'. But again, it is critical on how real is a reality program itself (Shrum, 2002).

\section{Social Construction of Reality}

The role of mass media in the process of the social construction of reality has a significant contribution to communication research. The research underlines that the media construct reality. The research focuses on how Australian media portrayals the reality of Indonesia as a country. Reality itself as what Berger and Luckmann try to allude is mainly a shorthand for 'what is regarded as reality', 'what is socially viewed as reality', and 'what is taken for granted as reality by the ordinary members of society' (Searle, 1995).

The social construction theory reveals the process on which human beings come together to build an understanding of the world. Meanings are developed together with other people, not separated from other people. The theory highlights how social interaction has a significant role in constructing meanings (Adoni \& Mane, 1984). Concerning the media reality, it assumed that media producers develop meanings. Media producers can present a reality which is consumed by the audience, in this case, Australians.

This study needs to elaborate on the social construction theory of reality to comprehend the social construction of mass media. It is a dialectical process where human beings act both as the creators and as products of the social world. In other words, society can be the object of the social world and also the subject of the social world. There are three types of reality implied in this dialectical process; an objective social reality that is experienced as the objective world existing outside the individual. The symbolic social reality which consists of any form of symbolic expression of objective reality such as art, literature, or media content. The subjective social reality, where both the objective and the symbolic realities become an input for the construction of the individual's subjective reality (Prasanti \& Indriani, 2016). In the discussion of the media, society is constructed, not a fixed reality. The media provides materials for the social construction process, which reproduces particular meanings. The media offer meanings, but it can be negotiated or rejected. The media cannot provide objective social reality because all facts are interpretation.

In the context of this research, the social construction theory stated how reality is constructed by humans subjectively through the mass media. The media content is a symbolic reality. The symbolic reality has multi-dimensions of reality because it implies an individual's perception of a shared symbol. Media puts itself as a filter on social themes, where media, on the other hand, loves dramatical situation, which leads the media to become bias in choosing what it will present for the public (Creswell \& Miller, 2000).

One research stated that there were two fundamental processes which involved media construction of social reality. First, 
the media was constructed through gatekeeping theories and news value, while the second explained how constructed selected issues based on framing theory (Yan \& Yan, 2020). The above explanation comprehends why audience focused on one selected reality. From this, it assumed that the media only bring out selected issues and events about Indonesia, which influence how Australians view Indonesia. As what Gamson states that ideally, the media is responsible for providing audiences with a coherent sense of the broader social forces that affect the conditions of their everyday lives (Gamson, 1992).

Related on this research, Freedman analyzed the representation of Australian media about Indonesia in three perspectives. The "liberal-pluralist" perspective which contained a lot of useful data about specific institutional limitations on journalists though ignoring broader social meanings of media representations. The "Culturalist" perspective where myths and codes are important and appear in analyzing Australian media, and their historical antecedents are tracked, however again there are often incomplete records of social structure. The political-economic perspective is useful on the structure of media regulation, social-economic regulations and has the power of forming media products, but ignoring regulating roles discourse and ideology (Freedman, 2000).

Media has always been involved in constructing social reality. There are multi reasons why media involves itself in presenting "constructed" reality. Media is known to 'summarize' the reality. Hence, this is because of many arguments. Media has limited space and time to present news (Suryadi, 2011) thoroughly. The obstacles above can lead to fabrication news which also can lead to social issues. Another argumentation on what Suyadi argued, which is very common is that media tends to present news that can draw the audience attention, news that sells and are exciting in the eye of the audience. Researches stated at least 11 values that can draw the public's attention; (1) the magnitude of how the news can be acknowledged nationwide or worldwide. (2) Proximity, which can be either geography proximity or psychology proximity, (3) actual, (4) medium to high impact in the surrounding area, (5) unusual, (6) news about public figures, (7) human interest, (8) news that is surprising, (9) news about sex, (10) conflict, and (11) pieces of information.

\section{Methodology}

This research was conducted through descriptive qualitative research. The qualitative paradigm assumes that reality is socially constructed and it is what participants perceive it to be (Maxwell \& Reybold, 2015). What the media portrays and constructs is what the audience perceive. There are four specific features in conducting qualitative research; the first one is to understand the participants' meanings. When it comes to an understanding' meanings', researches must then comprehend that every participant's meaning is based on each of their field of experience and also their frame of references.

Second, identify and acknowledge the influence of the specific contexts where the participants are situated. This research is situated in Australia, which means specific contexts are based on individual perceptions, values and beliefs. Third, explain that meanings and contexts lead to specific outcomes and last, explain explicitly that the subjectivity of the researcher is central to qualitative research (Creswell, 2009).

The data collection techniques used in this research were interview and documentation studies. Informants were selected by using purposive sampling. The characteristic of the informants was; (1) an Australian, (2) watched Television to gain Information (3) the informant had Indonesian friends and (4) the informant had a concern about how Australian media portrayed Indonesia. Ten informants were chosen; they were Australians. Jessica, 19 years old and was a 1st-year student of The University of New England in Armidale (UNE). Jane Ahlstrand, 36 years old, is a lecturer of UNE. Jori Bremmer, 25 years old, is a PhD student of UNE. Jori, who grew up in the Netherlands, looking at his background, stated that he was concerned about Indonesia as a country. Chelsea Piper, 19 years old was in her 2nd year in UNE. Jenny Evans, 55 years old, is a German lecturer in UNE. Luke Buckmaster, 50 years old, is a public servant in Canberra. Peter Hackney, 43 years old, is a journalist, Cassandra Edwards, 69 Years old is Retired. Matthew Hannay, 42 years old, is a farmer and David Wormleaton, 74 years old is a retired German teacher.

The interview linked mostly on the television channels watched and how much of news concerning Indonesia were broadcast. Though, there were two substantial questions that the researchers asked to the informants. The two questions included on how the media portrayed Indonesia as a country and how they viewed Indonesia after receiving information about Indonesia through the meda. All informants were interviewed in Armidale, Australia in March 2019. Eventhough the research was conducted a year ago, it has not really changed. Figure 1 showed one piece of information about how the coronavirus could trigger a prison riot. This news would be seen as a problematic issue for Indonesians. 


\section{Result}

\section{How the Australian Media Portrays Indonesia}

Based on the interview, the result showed that most Australians did not find news about Indonesia as real as how the Australian portrayed. Even though in some cases, they were concern about the story of Indonesia, especially relating to the news that could impact Australia as its neighbouring country, they still believed that there was more than what the news represented.

ABC Australia is the most trusted broadcaster; it delivers Australian stories to the audience that can be accessed around the world online, on mobile, social media through broadcasting on ABC Australia TV and Radio Australia. This channel delivers a mix of programs which include news, current affairs, comedies, documentaries, sport, drama and awardwinning programs. Even though $\mathrm{ABC}$ on television had its downfall in the mid 1990ies, the emerging of ABC online revealed a new space and attracted new audiences. (Burns, 2000).

Jessica said that ABC Channel often broadcast news about Indonesia. At the same time, Luke thought that there was not much coverage of stories from Indonesia in the Australian media, and when there was, it was not in great depth. It mostly talked about the complexity of Indonesia.

"They are only talking about the politics, corruption, the communication between the prime minister and Indonesia's president who often fail to agree, lately, Australian media often covers Indonesian election progress, and more about people come to the street and protest against government policy. Moreover, if there is a terror attack, all news is not in in-depth coverage". ${ }^{1}$

Jane another informant explained that the way Indonesia was portrayed was often more like a country that was prone to disasters, violence and often portrayed as a country that was a bit chaotic or dangerous, and also required help from Australia. She saw it as not overall very positive. Jane perceived it as a negative representation of Indonesia. She assumed that the media did not cover other parts of Indonesia which could represent far more positive. She assumed that the media needed something exciting, something dramatic.

Jessica stated that the media portrayed Indonesia as an unorganized and chaotic place for pedestrians and public transportations. Jessica made a comparison between both countries, 'As in Australia, the system is really organized, there are certain road people can't and can walk in. which in Indonesia it is a lot less organized'2. Jory, another informant, thought that the central issue of Indonesia was about the public transportation where it was not only about the traffic jam that took place most of the time and in most places, but also he heard a lot about infrastructural problems. He assumed how difficult it was to get from one point to the other and how difficult it was to rebuild places. Figure 2 is a piece of information related to the heavy traffic that occurred in Jakarta in the year 2019. As seen, readers could identify how massive the traffic is by looking at the picture.

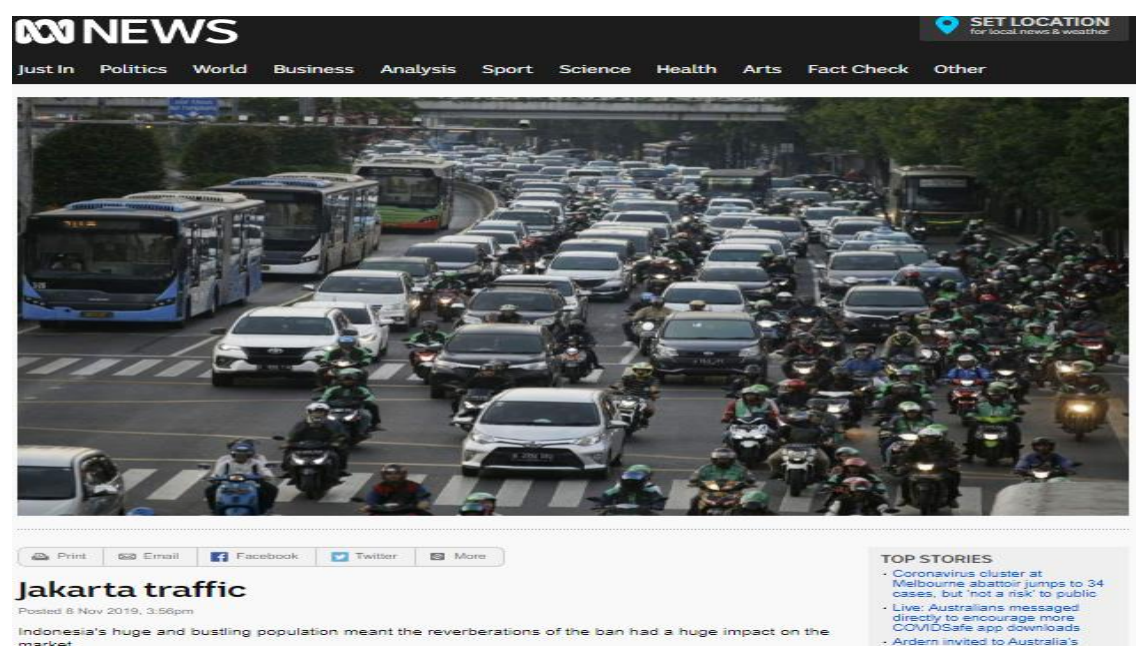

Figure 2. News of Traffic in Jakarta, Indonesia

Source: https://www.abc.net.au/news/2019

\footnotetext{
1 Interview with Luke, March 2019

2 Interview with Jessica, March 2019
} 
Most informants had the same perceptions about how the media portrayed Indonesia related to Tourism. Bali was mostly mentioned as a tourism place, and rarely showed any other parts of Indonesian beside Jakarta as the capital city. Most said that the media mostly only showed the holiday sites of Indonesia, especially Bali. Cassandra, even though that Bali was a country of its own and that Indonesia was in Bali. "The Media presents Bali as a place where people can go and party and be wild and do lots of dangerous things' stated Chelsea ${ }^{3}$. Even though there were promotions on how beautiful Bali was, there was also information on how dangerous it could be.

"Scenes of bombs in a hotel or a place in Jakarta a few years ago or gunfights on the streets present Indonesia as a dangerous place. However, then there is also, a more recent site where it shows like natural beauty and a cultural aspect of it in a real-life" (Chelsea, 2019)

Luke regretted on how it was more about Bali. He stated that Australians were not aware of other areas except for Bali; they only knew a little bit about Jakarta or any other cities around Indonesia. The Media did not seem to show about anything else anywhere else in Indonesia; Luke believed ${ }^{4}$. Luke was sure that there were other exciting places to visit in Indonesia, for example, Lombok.

Some informants explained how Indonesia had a lot of strict and hard laws. One told an example of some news about an incident with the Australian citizen tourists who was in trouble with the Indonesian law. He recalled one as "Bali Nine". Bali Nine was an incident in April 2005; where officers arrested 9 Australians. Officers arrested Martin Stephens, Renae Lawrence, and Scott Rush for bringing packages of heroin strapped to their bodies at Denpasar airport. The law alleged them for also attempting to smuggle more than eight kilograms out of Indonesia (M. Morgan, 2008). Australians were concern about this incident. Though Luke agreed that Indonesia was an excellent place for tourism, he also acknowledged that tourists should also be aware of the laws applied in Indonesia.

Relating to Indonesia as an excellent tourist place, Cassandra stated that the media informed many travel warnings. On those warnings, she then assumed that there might have been problems in Jakarta, and the media warned people not to go to Bali. She recalled what happened in East Timor that also drew much of the public's attention, especially for Australia as it was proximal to Australia.

Jenny explained that the Media was very diverse. So, she thought that everyone had their perspective in seeing the media. It depended on which way people looked - this statement correspondent on some superficials programs, and sensational programs dealing with Indonesia. The Media shows that Indonesia and Australia are generally in relation, especially in relating to its economic and political relation. Jenny recalled on the news about the Presiden election of Indonesia, which was a great interest for Australians.

Matthew had the same idea as other informants. He often heard about the negatives things about Indonesia, like the deforestation in Kalimantan and Sumatra. Also, he often heard there was a fire that burnt down half of the forest. He assumed that Indonesia needed help to distinguish the fire from the Australia government. Another statement that Matthew gave was about Indonesians as being abusive to animals. People often hunted and killed protected animals such as the orangutan, dolphins, and rhinoceros. He wondered what actions that the Indonesian government had taken to stop that problem. Besides that, he often heard the Media covers the plastic waste that polluted the river, like Citarum River, the longest river in West Java.

Jane explained that the overall coverage of Indonesia tended to focus mainly on disasters, conflicts, people smuggling, some of the media also covered politics in Indonesia and how corrupted the politicians were. The media in Australia portrayed Indonesia, unfortunately as a place that had many troubles. Australians only heard about Indonesia in the media when there was a natural disaster, tsunami, or the earthquake or when terrorism hit

\footnotetext{
3 Interviewed in March 2019

4 Interviewed in March 2019
} 


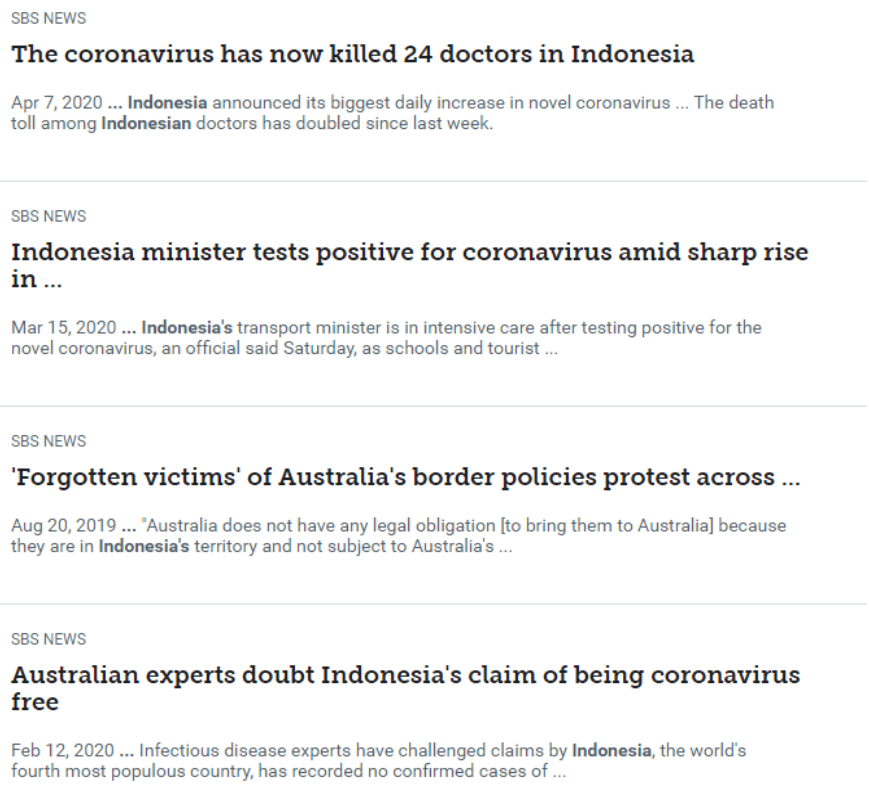

Figure 3. Headlines on Indonesia in SBS news

Source: https://www.sbs.com.au/

In the beginning year of 2020, the World Health Organization announced that the coronavirus was a pandemic that had shattered countries worldwide (Ducharme, 2020), many information spreads were all about the virus. This issue made more headlines in the Australian Media about Indonesia that linked to the coronavirus. As seen in figure 3, the headlines in SBS.com.au were more about problematic information circulating the virus. It persumed that the media coverage on Indonesia did not change much from 2019.

\section{How Australians Perceive Indonesia}

Despite the news shown on the media, Jessica still considered that Indonesia was a beautiful country and shared good images of agricultures. However, it still had some chaos which she thought a lot of Australians did not understand. Australians are used to an organized transportation system, so they can not relate to what is going on in Indonesia, which is chaotic. By the chaos here means as the unorganized system of pedestrian and public transportations.

Jane would see Indonesia as a kind of struggling country, and not as good as Australia. Moreover, Australia is more potent than Indonesia, so Australia needed to help Indonesia. She also saw it as a religious country. It had unstable political situations. Base on her opinions on what she saw on the media, she would see it as a dangerous, unruly and unstable place. Because of its proximity to Australia, it became a threat. However, again Jane knew more about Indonesia, so she did not have that opinion than what she got from the media. Meanwhile, Jori has been to Indonesia a couple of times, so he alone had a subjective reality about Indonesia. So, he admitted it was true how Indonesians commuted, but he presumed that people knew what they were doing and everything functions. So, he concluded that it might not be chaotic for the people who lived in Indonesia. It might only be chaotic for the tourists who were not aware of it and might need to adapt fast. Australians are in the habit of no traffic. If there is traffic, there usually be warnings and Australians are used to have a time-table for any public transportation.

Jenny saw that there was a significant excitement part of Australia about the potential trade with Indonesia. Indonesia is as a tourist destination, or a lot of Australians look Indonesia as a place they want to go to, Australians want to travel there. They think of it is an amiable and welcoming country. But also quite different. Often issues about Islam have much tension with terrorist's thread. Moreover, there is also much cooperation between Indonesia and Australia. So, Jenny saw Indonesia portrayed in the media on the whole very positively, and people were keen on a deeper relationship with Indonesia.

Luke assumed that Australians did not think Indonesia as a corrupted country. It was something that they did not know very well. Peter, on the contrary, did not know much about Indonesia, even though it is a neighbour. Peter stated that the average Australians thought that Indonesia was very Islamic; they did not realize there were other religions. Furthermore, when they heard about Indonesia, they heard about an Australian getting in trouble like Schapelle Corby or Bali 9. So, it seemed to have negative aspects, but then again peter acknowledged that the media only covered what could draw the public attention. 
Matthew, as a farmer himself, he admitted that Indonesia had beautiful places, and its agriculture was a blessing. However, he was sorry that the Indonesian government seemed unable to take care of it.

\section{Discussion}

Today's society constructs its opinions in most cases through the media and in the same way, chooses to perceive a group of society or even a country on how the media portrays it - in the qualitative analysis conducted. Research shows a conclusion that these perceptions are quite sharp though they still have this seeming self-awareness that the Media tends to point out dramatical information. According to the result, most Australians are concern about what the media has to say about Indonesia. They have perceptions about Indonesia because of the media. They still admit that the media can also be too dramatic and focuses on negative things about a country. The Media chosen was Australian Media. Australian Media referred to any news or information that are broadcast in Australia or representing Australia. The Australian media has at least portrayed five categories that were seen by the ten informants; below are the explanations.

First, Indonesia is prone to disaster. There is so many news in the media that shows that Indonesia suffers natural disasters frequently. Earthquakes, flood, tsunami, bush fires and landslides are the most common issue in the Australian Media. This kind of news draws much intention in the eye of Australians. Why does it draw much attention? One of the reason is that Indonesia has geographical proximity to Australia. Those disasters can impact Australia itself. It could impact as a human interest, where Australia needs to lend a hand, or those disasters could impact geographically.

Second, Indonesia has high complexity, especially in politics. Indonesian political conflicts that emerge in the Australian Media demonstrates a negative representation. It shows much tension in the Indonesian government. Australians see Indonesia as an unstable country. As mentioned before, news about a public figure draws attention; this relates to Indonesian's President. How the president solves Indonesian problems, and international relationships seem to magnetize the audience.

Third, Indonesia is an unorganized and chaotic place for commuters. Most Australians wonder how Indonesian go from one place to another without being stressful not only because of the disorganized routes but also massive traffic jam that could be seen everywhere in the media. The traffic shown in the Australian Media seemed unusual and utterly confusing. Australia has very organized routes for commuters, so what they see in the media about the massive traffic in Indonesia might be shocking.

Fourth, Bali is known as a beautiful tourists place. Australians think that Bali is a country of its own, and it does not have anything to do with Indonesia, or in some cases, Australians think that Indonesia is in Bali. One of the reason is that the Australian Media highlights beautiful commercials about Bali. Most Australians think that the only beautiful tourist place is only in Bali. They admit they do not know other places which might be a better destination for going on holidays. The media often only covers news that happens in Bali. Most do not even know that Jakarta or even Bandung is Indonesia. As mentioned before, Australians love going on holidays as most informants said that they are continually thinking about a holiday, they love to go there for holidays. Since the symbolic reality perceived are mostly media contents about how Bali is an excellent destination for having a holiday. People who have never been to Indonesia would say that they would never go there.

Fifth, Indonesia is a violent and dangerous place; this relates to terrorists and drug smugglers. Who can ever forget the devastating tragedy of Bali bombing by terrorists that occurred in 2002 and killed most Australians? This tragedy has become a scar for Australians. Australians will never forget, and neither will the Media. The Australian Media keeps repeating this news over and over again. Another incident known as Bali 9 is also a sign where drug dealers can run around relatively free in Bali. News about the execution of Bali 9 or because of what is happening in Timor add more beliefs that Indonesia is a dangerous place.

The five categories is coherent on what Vera (2016) mentioned that the mass media system goes through internal codes. The media seemed to have criteria on information that can draw the audience attention. News reality is often decontextualized, what the media presents blur the connection between the news reality and its original surrounding context (Bennett, 2005; Price, 2010). The media seemingly allows information to spread to society without being criticized more about the facts. The society tends to take it for granted without critical interpretation. The development of media has a lot to do on how people attain information. Technology enhances the speed in spreading information. The technology gives more power to the media to construct reality (Nišić \& Plavšić, 2014). In this case, the Australian media has constructed reality of Indonesia.

Based on Freedman (2000) arguments, the "Culturalist" perspective is seen as the most perspective used by the Australian in viewing Indonesia. Australians encoded meanings from the media based on their cultural references. At the same time, some admitted to understanding it more than other Australians primarily when they discussed how Indonesian commute, which is quite different on how Australians commute. 
Despite what the Australian Media constructs the reality of Indonesia, the informants still believe that there are more about Indonesia that is positive information. Though on the contrary, some Australians see Indonesia as a helpless country who is desperate for needing help from other countries to deal with the problems Indonesia has. Most informants believe that Indonesia is a young nation, and as a young nation, it often has a lot of issues, unorganized, and still developing. So, any problems related is something that a new nation must face as a developing process.

Australians' preception based on media-constructed creates subjective social reality. The subjective social reality is where both the objective and the symbolic realities become an input for the construction of the individual's subjective reality (Prasanti \& Indriani, 2016). The media reality in which Australian media show the reality of Indonesian, the next part of the research is about how the Australian perceive Indonesia after obtaining information about Indonesia through the media. The media content itself is what we call the symbolic reality, and this is why the researchers analyzed it with the social construction of reality theory. As mentioned before, society itself is an individual product where it becomes an objective reality (Vera, 2016). In this case, what the Australian media offered is the objective reality of Indonesia.

Unfortunately, The Australian Media portrays Indonesia quite harmful. And probably out of date as well. News, in general, is often negative anywhere, especially in Indonesia's case. Nevertheless, they assumed that the Australian Media is not very good at reporting them. Nohrstedt and Ottosen (2005) stated that the media could also construct multiple and often conflicting realities. They stated that international comparative analyses have shown how the press presents the US and "others" in different countries in the context of the "war on terror" and the war in, or on what Wolfsfeld et al. (2002) pointed out an example how media in Israel and Jordan each portrayed the peace process (M. Morgan, 2008). They know that Media loves dramatic stories as what Morgan implied that Stories of crime and violence dominate news coverage.

\section{Limitations and Study Forward}

Results of this research only show categories of how Australian media presents the reality of Indonesia and how Australians preceive it. Australians seemed to acknowledge that the media reality do not show information as a whole and the media reality seemed to only present news which can draw the audience' attention. This research can not identify how far Australian media can influence someone's preception and which media influence more. In the digital era, the term multimedia seemed to be more relevant, in this case, a study on multimedia and its complexity in it is strongly recommended.

\section{Acknowledgement}

We would like to show our gratitude to the Faculty of Communication Science Unisba which held the Annual Conference of Communication, Media and Culture (ACCOMAC) II 2019 where researchers could share their paper.

\section{Future Scope}

This study only begins to reveal the way Australians perceive Indonesian through media reality. There are still unanswered questions that researchers need to reveal. The digital era and the post-truth era have become alarming and have changed how the Media construct news and also how people search for news. Researchers should go into a much higher degree level to reveal what reality is.

\section{Reference}

Adoni, H., \& Mane, S. (1984). MEDIA AND THE SOCIAL CONSTRUCTION OF REALITY. Communication Research, 11(3), 323-340. https://doi.org/10.1177/009365084011003001

Bennett, W. L. (2005). News as Reality TV: Election Coverage and the Democratization of Truth. Critical Studies in Media Communication. Retrieved from

http://web.ebscohost.com.ezproxy.library.wisc.edu/ehost/pdfviewer/pdfviewer?vid=3\&hid=110\&sid=a194972f94ba-49b1-9ecc-605844857516@sessionmgr114

Burns, M. (2000). ABC Online: A Prehistory. Media International Australia Incorporating Culture and Policy, 97(1), 91103. https://doi.org/10.1177/1329878x0009700112

Creswell, J. W. (2009). Research design : qualitative, quantitative, and mixed methods approaches. Sage.

Creswell, J. W., \& Miller, D. L. (2000). Determining Validity in Qualitative Inquiry. In Theory Into Practice. https://doi.org/10.1207/s15430421tip3903_2

Ducharme, J. (2020). The WHO Just Declared Coronavirus COVID-19 a Pandemic | Time. Retrieved April 22, 2020, from 2020 TIME USA website: https://time.com/5791661/who-coronavirus-pandemic-declaration/

Freedman, N. (2000). Indonesia in Australian media - A literature review. In Asia Pacific Media Educator (Vol. 8). Retrieved from https://ro.uow.edu.au/apmeAvailableat:https://ro.uow.edu.au/apme/vol1/iss8/13

Fürsich, E. (2010). Media and the representation of Others. International Social Science Journal, 61(199), 113-130. 
https://doi.org/10.1111/j.1468-2451.2010.01751.x

Gamson, W. (1992). Media Images and the Social Construction of Reality. Annual Review of Sociology, 18(1), 373-393. https://doi.org/10.1146/annurev.soc.18.1.373

Hardt, H. (2002). The Reality of the Mass Media. Journal of Communication Inquiry, 26, 96-97. https://doi.org/10.1177/019685990202600108

Harvey, A. (2020). Orangutans among thousands of animals at risk of starvation in Indonesian zoos under coronavirus lockdown, officials warn - ABC News. Retrieved May 6, 2020, from ABC News website: https://www.abc.net.au/news/2020-05-03/indonesia-orangutans-animals-at-risk-of-starvationcoronavirus/12209354

Hoffman, L. H., \& Glynn, C. J. (2013). Media and Perceptions of Reality. In The International Encyclopedia of Communication. https://doi.org/10.1002/9781405186407.wbiecm044.pub2

Maxwell, J. A., \& Reybold, L. E. (2015). Qualitative Research. In International Encyclopedia of the Social \& Behavioral Sciences: Second Edition (pp. 685-689). https://doi.org/10.1016/B978-0-08-097086-8.10558-6

Morgan, M. (2008). Reality and Media Reality. In The International Encyclopedia of Communication. https://doi.org/10.1002/9781405186407.wbiecr015

Morgan, R. (2019). Australians still spend more time watching TV than using the internet at home - Roy Morgan Research. Retrieved November 18, 2019, from

http://www.roymorgan.com/findings/7069-more-time-watching-television-than-using-internet-at-home-australiaseptember-2016-201611291605

Nielson. (2018). Screen Time Still an Australian Pastime - Nielsen. Retrieved May 2, 2020, from 2020 The Nielsen Company (US) website:

https://www.nielsen.com/au/en/insights/report/2018/screen-time-still-an-australian-pastime/

Nišić, V., \& Plavšić, D. (2014). Th e role of media in the construction of social reality. Sociological Discourse, 4(7), 7381. https://doi.org/10.7251/SOCEN1407073N

Pfefferbaum, B., Nixon, S. J., Tivis, R. D., Doughty, D. E., Pynoos, R. S., Gurwitch, R. H., \& Foy, D. W. (2001). Television exposure in children after a terrorist incident. Psychiatry, 64(3), 202-211. https://doi.org/10.1521/psyc.64.3.202.18462

Prasanti, D., \& Indriani, S. S. (2016). PEMAKNAAN SIMBOL DALAM KOMUNITAS "BROTHERHOOD" (Konstruksi Makna Simbol sebagai Identitas Diri dalam Komunitas "Brotherhood" di Bandung) | Prasanti | SEMIOTIKA: Jurnal Komunikasi. Semiotika, 10(1), 1-24. Retrieved from https://journal.ubm.ac.id/index.php/semiotika/article/view/25/22

Price, E. (2010, June). Reinforcing the myth: Constructing Australian identity in "reality TV." Continuum, Vol. 24, pp. 451-459. https://doi.org/10.1080/10304311003703157

Santoso, P. (2016). KONSTRUKSI SOSIAL MEDIA MASSA. In AL-BALAGH: Jurnal Komunikasi Islam (Vol. 1).

Searle, J. R. (1995). Construction of social reality. In The Free Press.

Shrum, L. J. (2002). (21) (PDF) Media Consumption and Perceptions of Social Reality: Effects and Underlying Processes. In D. Bryant, Jennings ; Zillmann (Ed.), Media Effects. Advances in Theory and Research (pp. 50-69). Retrieved from

https://www.researchgate.net/publication/209410195_Media_Consumption_and_Perceptions_of_Social_Reality_ Effects_and_Underlying_Processes

Suryadi, I. (2011). Peran Media Massa dalam Membentuk Realitas Sosial. Academica Fisip Untad, 3(2), 634-646. Retrieved from

https://media.neliti.com/media/publications/28520-ID-peran-media-massa-dalam-membentuk-realitas-sosial.pdf

Vavla, F., \& Hasalla, G. (2015). Cultivating Reality through Stereotyping in the Media. Academic Journal of Interdisciplinary Studies. https://doi.org/10.5901/ajis.2015.v4n3s1p618

Vera, H. (2016). Rebuilding a Classic: The Social Construction of Reality at 50. Cultural Sociology, 10(1), 3-20. https://doi.org/10.1177/1749975515617489

Vu, H. T., \& Lee, T. T. (2012). State-press relations revisited: a case study on how American media portray the post-war Vietnam. Asian Journal of Communication, 22(6), 549-565. https://doi.org/10.1080/01292986.2012.717093

Wakary, G. (2020, April 16). Coronavirus measures trigger prison riot in Indonesia - ABC News. Retrieved from 
https://abcnews.go.com/Health/wireStory/coronavirus-measures-trigger-prison-riot-indonesia-70103343

Yan, F., \& Yan, F. (2020). Media Construction of Social Reality. In Image, Reality and Media Construction (pp. 41-63). https://doi.org/10.1007/978-981-32-9076-1_3

\section{Copyrights}

Copyright for this article is retained by the author(s), with first publication rights granted to the journal.

This is an open-access article distributed under the terms and conditions of the Creative Commons Attribution license which permits unrestricted use, distribution, and reproduction in any medium, provided the original work is properly cited. 